\title{
Upaya Pembentukan Nilai Karakter Peduli Sosial dan Lingkungan melalui Pendidikan Kepramukaan di SMP Negeri 1 Cipari Kabupaten Cilacap
}

\author{
Satrio Awal Handoko, Tukidi, Asep Ginanjar ${ }^{\varpi}$
}

Prodi Pendidikan IPS, Fakultas Ilmu Sosial, Universitas Negeri Semarang, Indonesia

\section{Info Artikel \\ Sejarah Artikel: \\ Disubmit: Januari 2019 \\ Direvisi: Februari 2019 \\ Diteirma: Maret 2019 \\ Keywords: \\ character education; values character social care; environmental care character values; education scouting}

\begin{abstract}
Abstrak
Tujuan dari penelitian ini adalah (1) Mengetahui penerapan nilai karakter peduli sosial melalui pendidikan kepramukaan pada siswa di SMPN 1 Cipari, (2) Mengetahui penerapan nilai karakter peduli lingkungan melalui pendidikan kepramukaan pada siswa di SMPN 1 Cipari, (3) Mengetahui faktor pendorong dan penghambat dalam penerapan nilai karakter peduli sosial melalui pendidikan kepramukaan, (4) Mengetahui faktor pendorong dan penghambat dalam penerapan nilai karakter peduli lingkungan melalui pendidikan kepramukaan. Jenis penelitian yang digunakan pada penelitian ini adalah penelitian lapangan atau kancah (field research) dengan model kualitatif deskriptif. Hasil penelitian menunjukkan bahwa (1) Nilai karakter peduli sosial dapat diterapkan melalui pendidikan kepramukaan, (2) Nilai karakter peduli lingkungn dapat diterapkan melalui pendidikan kepramukaan (3) Terdapat berbagai faktor pendorong dan penghambat dalam penerapan nilai karakter peduli sosial melalui pendidikan kepramukaan, (4) Terdapat berbagai faktor pendorong dan penghambat dalam penerapan nilai karakter peduli lingkungan melalui pendidikan kepramukaan.
\end{abstract}

Abstract

The purpose of this study were (1) Determine the application of the character values of social care through education scouting on students at SMPN 1 Cipari, (2) Determine the application of the character values environmental awareness through education scouting on students at SMPN 1 Cipari, (3) Knowing the factors driving and inhibiting the implementation of the character values social care through education scouting, (3) Knowing the factors driving and inhibiting the implementation of the character values matter educational environment through scouting. This type of research used in this research is the field or arena (field research) with descriptive qualitative model. . The results of the study explained that, (1) Values of social care character can be applied through scouting education. (2) Value character matter of an environmental can be applied through education scouting (3) There are many factors driving and inhibiting the implementation of the character values social care through education scouting, (4) There are many factors driving and inhibiting the implementation of eco-character values through education scouting.

(C) 2019 Universitas Negeri Semarang 


\section{PENDAHULUAN}

Pendidikan merupakan proses dari serangkaian kegiatan pembelajaran yang berlangsung sepanjang zaman dalam kehidupan yang terus menerus berkembang seiring dengan kemajuan kehidupan. Karena hal tersebut, maka pendidikan merupakan hal yang penting dalam pembangunan dan kehidupan bermasyarakat. Dalam UU Republik Indonesia No. 20 Tahun 2003 ditegaskan pentingnya pendidikan yaitu sebagai berikut: "Pendidikan adalah usaha sadar dan terencana untuk mewujudkan suasana belajar dan proses pembelajaran agar siswa secara aktif mengembangkan potensi dirinya untuk memiliki kekuatan spiritual, keagamaan, pendidikan diri, kepribadian, kecerdasan, akhlak mulia serta keterampilan yang diperlukan dirinya, masyarakat, bangsa, dan negara". Pada saat ini, nilai-nilai tersebut sudah mulai menghilang karena sikap manusia yang tidak pernah puas. Kemajuan teknologi juga mempengaruhi pudarnya nilai-nilai budi pekerti seorang manusia.

Pada awal bulan Februari terjadi kisah miris di dunia pendidikan, seperti yang diberitakan oleh tribunnews.com seorang siswa menganiaya guru hingga tewas terjadi pada salah satu sekolah di Sampang, Jawa Timur. Selain masalah moral, masalah kepedulian siswa terhadap lingkungan semakin hari semakin berkurang. Terbukti dengan acuhnya siswa terhadap kebersihan disekitarnya. Kementerian Kehutanan dalam website resminya merilis data bahwa setiap tahunnya angka kerusakan lingkungan mengalami peningkatan di berbagai daerah. Tidak membuang sampah pada tempatnya merupakan salah satu hal kecil yang dapat menyebabkan kerusakan lingkungan yang lebih besar, contohnya banjir dan yang pada saat ini sering terjadi. Mencoret-coret dinding sekolah juga sering dilakukan siswa, terbukti dengan mudahnya kita menemukan coretan di sekolah yang dilakukan oleh siswa. (tribunnews.com).

Saat ini pemerintah telah menyiapkan berbagai kebijakan terkait dengan pendidikan karakter dan penguatannya. Hal ini dapat dilihat dari penerapan kurikulum baru, yaitu kurikulum 2013 dimana pendidikan nasional harus berfungsi secara optimal sebagai sarana utama dalam pembangunan bangsa berserta karakter yang dimiliki. Sesuai dengan tujuan pendidikan nasional, secara keseluruhan telah diatur dalam Undang-Undang Republik Indonesia Nomor 20 Tahun 2003 tentang Sistem Pendidikan Nasional.

Karakter mempengaruhi pola pikir seseorang yang pada akhirnya akan berpengaruh pada cara seorang tersebut menjalani sesuatu dan mengambil tindakan. Salah satu karakter yang berpengaruh adalah peduli sosial dan peduli lingkungan. Penerapan sikap sosial harus dimulai sedini mungkin, dilaksanakan dalam segala aspek kehidupan, dan harus terus diulang-ulang oleh para pendidik dalam berbagai mata pelajaran sehingga memberikan pengaruh yang baik kepada para siswa. Selain pemberian karakter sikap sosial dalam pembelajaran, metode pelajaran yang digunakan oleh pendidik dalam mengajar juga merupakan hal yang penting karena hal tersebut akan mempengaruhi keberhasilan dalam menerapkan pendidikan karakter pada diri siswa. Untuk itu pendidikan karakter dapat diberikan melalui jalur pendidikan. Mata pelajaran IPS dapat menjadi salah satu sarana untuk membentuk karakter siswa dengan nilai-nilai sosial yang ada didalamnya. Guru mata pelajaran IPS dapat mengaplikasikan metode pembelajaran yang variatif guna membentuk karakter siswa. Namun, penerapan nilai karakter tidak cukup hanya melalui pembelajaran didalam kelas saja, pembentukan karakter siswa juga harus didukung dengan kegiatan diluar kelas salah satunya adalah dengan pendidikan kepramukaan. Pendidikan karakter dapat diterapkan melalui kode kehormatan yang dimiliki Gerakan Pramuka. Dasa dharma kedua yang berbunyi cinta alam dan kasih sayang sesama manusia sesuai dengan karakter peduli sosial dan peduli lingkungan. Pramuka adalah proses pendidikan di luar lingkungan sekolah dan di luar lingkungan keluarga dalam bentuk kegiatan menarik, menyenangkan, sehat, teratur, terarah, praktis yang dilakukan di alam terbuka 
yang sasaran akhirya adalah untuk pembentukan watak, akhlak dan budi pekerti luhur. (Gunawan, 2012:265).

\section{METODE}

Jenis penelitian yang digunakan pada penelitian ini adalah penelitian lapangan atau kancah (field research) dengan model kualitatif deskriptif, yaitu penelitian yang pengumpulan datanya dilakukan di lapangan, seperti dilingkungan masyarakat, lembaga-lembaga dan organisasi kemasyarakatan dan lembaga pendidikan baik formal maupun non formal. Subjek penelitian ini yaitu pembina pramuka, anggota pramuka dan kepala sekolah di SMP Negeri 1 Cipari. Informan utama dalam penelitian ini adalah pembina pramuka. Peneliti juga melibatkan informan pendukung. Informan pendukung adalah individu yang memberikan informasi pendukung terkait penelitian ini dan untuk membandingkan hasil data yang didapat dari informan utama. Informan pendukung dalam penelitian ini adalah anggota pramuka dan kepala sekolah SMP Negeri 1 Cipari. Alat dan teknik pengumupulan data adalah sesuatu yang digunakan dalam memperoleh data. Penelitian ini menggunakan pendekatan kualitatif, sehingga untuk mengumpulkan data yang tepat ialah menggunakan metode observasi, wawancara dan dokumentasi yang sesuai dengan permasalahan yang akan diteliti. Observasi ini dilakukan oleh peneliti secara langsung. Teknik observasi yang digunakan dalam penelitian ini adalah teknik berperan serta. Peneliti ikut serta dalam kegiatan kepramukaan di SMP Negeri 1 Cipari. Observasi dilakukan sebelum penulis melakukan penelitian, yaitu selama 1 minggu mulai pada tanggal 19-24 Maret 2018. Observasi dilakaukan oleh peneliti untuk mengetahui lingkungan sekolah yang dijadikan penelitian, latar belakang sekolah, letak sekolah, perilaku siswa dalam kegiatan ekstrakurikuler pramuka, tata tertib sekolah, data siswa, tenaga pendidik dan non kependidikan, dan kegiatan ekstrakurikuler pramuka di SMP Negeri 1 Cipari. Selain itu juga peneliti mengamati proses penanaman karakter secara langsung maupun tidak langsung. Penulis melakukan wawancara terstruktur terhadap kepala sekolah, pembina pramuka dan anggota pramuka untuk memperoleh data yang berkaitan dengan penerapan nilai karakter peduli sosial dan peduli lingkungan di SMP Negeri 1 Cipari. Wawancara pertama dilakukan pada hari Sabtu, tanggal 7 April 2018 pukul 12.30-13.30 WIB. Wawancara ini dilakukan dengan pembina pramuka di SMP Negeri 1 Cipari yaitu bapak Ahmad Furqon. Informan menyambut baik peneliti ketika ingin melakukan wawancara, karena sebelumnya peneliti dan informan telah membuat janji untuk melakukan wawancara. Proses wawancara berjalan lancar karena susasana yang kondusif, dan informan memiliki waktu yang senggang. Selain itu, informan juga menjawab pertanyaan dari peneliti secara terbuka. Wawancara kedua dilakukan pada hari Rabu, tanggal 18 April 2018 pukul 10.00-11.30 WIB. Wawancara ini dilakukan dengan kepala SMP Negeri 1 Cipari yaitu bapak R. Sri Pramana Budiarsa. Informan begitu ramah dan menyambut hangat kedatangan peneliti. Proses wawancara berjalan lancar, bahkan diselingi dengan wejangan-wejangan yang menginspirasi peneliti untuk dunia kepramukaan. Selain itu informan juga menjawab pertanyaan peneliti secara terbuka. Wawancara terakhir dilakukan peneliti pada hari Kamis, 19 April 2018. Wawancara dilakukan pukul 08.00-13.00 WIB. Wawancara ini dilakukan dengan anggota pramuka dan dewan penggalang SMP Negeri 1 Cipari. Informan menjawab semua pertanyaan dengan jelas walaupun sesekali harus diberi rangsangan jawaban agar memberikan keterangan yang lebih mendalam kepada peneliti. Dokumentasi dilakukan oleh peneliti untuk memperoleh data pendukung sebagai bukti penguat dari hasil penelitian. Dokumentasi pada penelitian ini yaitu foto-foto sekolah, kegiatan ekstrakurikuler pramuka, penanaman nilai karakter peduli sosial dan peduli lingkungan di SMP Negeri 1 Cipari, arsip data kependidikan dan kurikulum. Kegiatan dokumentasi dilakukan oleh peneliti terhitung mulai awal melakukan observasi yaitu pada tanggal 19 Maret 2018 sampai akhir melakukan 
penelitian yaitu pada tanggal 21 April 2018. Triangulasi adalah teknik pemeriksaan keabsahan data yang memanfaatkan sesuatu yang lain. Selain data itu untuk keperluan pengecekan atau sebagai pembanding terhadap data itu. Teknik triangulasi yang paling banyak digunakan ialah pemeriksaan melalui sumber lainnya ada empat macam triangulasi sebagai teknik pemeriksaan yang memanfaatkan penggunaan sumber, metode, penyidikan dan teori (Moleong, 2011:330). Penelitian ini menggunakan triangulasi sumber dan triangulasi metode. Triangulasi dengan sumber berarti membandingkan dan mengecek balik derajat kepercayaan suatu informan yang diperoleh melalui waktu dan alat yang berbeda dalam penelitian kualitatif (Patton dalam Sugiyono 2015:330). Triangulasi sumber data yang digunakan dalam penelitian ini yaitu sumber observasi, sumber wawancara dan sumber dokumentasi. Peneliti membandingkan data hasil wawancara antar informan terkait penerapan nilai karakter peduli sosial dan peduli lingkungan melalui esktrakulikuler pramuka di SMP Negeri 1 Cipari. Berdasarkan hasil wawancara dengan bapak Ahmad Furqon sebagai pembina pramuka terkait pembentukan peduli lingkungan melalui pendidikan kepramukaan, didapatkan hasil wawancara sebagai berikut "Pelaksanaanya dilakukan setiap kegiatan pramuka. Selalu memberikan arahan dan pemngawasan setelahnya. Siswa diajarkan tentang kepedulian terhadap lingkungan sekitar bahawa kita tidak hidup sendiri, ada lingkungan yang menjadi penting untuk kehidupan kita. Seperti pemberian materi tentang toga, dan peduli terhadap kebersihan" (Wawancara pada tanggal 7 April 2018 pukul 12.30). Informasi yang didapatkan dari Bapak Ahmad Furqon menjelaskan bahwa pembentukan karakter peduli lingkungan dilakukan setiap pelaksanaan kegaiatan pramuka, dengan didukung oleh materi-materi yang berkaitan tentang lingkungan dan menerapkannya dalam kehidupan seharihari. Hasil temuan tersebut, oleh peneliti mencoba membandingkan dengan hasil wawancara yang didapatkan dari anggota pramuka di SMP Negeri 1 Cipari. Tujuan pembandingan ini yaitu agar data yang diperoleh oleh peneliti bersifat objektif. Salah satu anggota pramuka SMP Negeri 1 Cipari yang bernama Transiska Silvia mengungkapkan bahwa "Pembina pramuka selalu memberi nasihat, dan memberi arahan untuk kegiatan pramuka." (wawancara pada tanggal 19 April 2018 pukul 11.00 WIB). Berdasarkan hasil wawancara dengan anggota pramuka dapat diketahui dan dijelaskan bahwa pembina pramuka yaitu Bapak Ahmad Furqon selalu memberi nasihat dan arahan kepada anggota pramuka. Anggota pramuka diberikan pengetahuan agar dapat mengikuti kegiatan pramuka dengan baik dan menjalankan apa yang dikehendaki oleh pemnbina pramuka.

Teknik analisis data yang digunakan pada penelitian ini yaitu analisis data kualitatif dilakukan beberapa tahap yaitu pengumpulan data, reduksi data, penyajian data dan menarik kesimpulan. Pengumpulan data dalam penelitian ini dilakukan menggunakan dengan metode wawancara, observasi dan dokumentasi. Data-data tersebut diperoleh dari subjek penelitian. Subjek penelitian dalam penelitian ini yaitu pembina pramuka, kepala sekolah, dan anggota pramuka. Reduksi data pada penelitian ini dilakukan dengan menganalisis dan menggolongkan data-data yang diperoleh di lapangan. Semua data yang diperoleh peneliti pada dasarnya masih secara umum, untuk mempermudah menganalisis data maka data yang diperoleh dipilih. Data yang sesuai dengan penelitian maka akan digunakan dan data yang tidak dibutuhkan akan dibuang peneliti. Data disajikan setelah direduksi. Setelah data terpilih maka data siap disusun secara sistematis. Sehingga data siap untuk disajikan. Data yang disajikan pada penelitian ini terkait tentang upaya pembentukan nilai karakter peduli sosial dan peduli lingkungan melalui ekstrakurikuler pramuka di SMP Negeri 1 Cipari. Reduksi data disajikan dengan konsep yang dibuat oleh peneliti. Peneliti menuliskan data yang diperoleh di lapangan yang telah dikelompokkan berdasarkan rumusan masalah. Data yang disajikan merupakan data hasil penelitian yang telah dilakukan oleh peneliti. Penelitian ini 
menarik kesimpulan dari proses awal hingga proses penyajian data. Kesimpulan yang diambil menjawab rumusan masalah yang telah dirumuskan. Data-data yang diperoleh dari observasi, wawancara dan dokumentasi, kemudian ditarik kesimpulan. Simpulan yang sajikan tidak lepas dari fokus penelitian yaitu upaya pembentukan nilai karakter peduli sosial dan peduli lingkungan melalui pendidikan kepramukaan di SMP Negeri 1 Cipari keempat proses metode penelitian ini saling berkaitan, model analisis yang digunakan dalam penelitian ini adalah adalah "Analisis Interaksi" artinya analisis dilakukan dalam bentuk interaksi pada keempat tahap tersebut.

\section{HASIL DAN PEMBAHASAN}

Hasil wawancara secara mendalam dan pengamatan yang dilakukan oleh peneliti ditemukan bahwa kegiatan ektrakulikuler pramuka di SMP Negeri 1 Cipari berjalan bisa dikatakan berjalan dengan baik. Bapak Ahmad Furqon, pembina pramuka SMP Negeri 1 Cipari menyatakan bahwa "Untuk ekstrakuliler pramuka di tahun 2017 kemarin sudah masuk kurikulum 2013, disitu tertera tentang ekstrakurikuler wajib yang harus dilaksanakan untuk siswa, khususnya SMP. Jadi, dari kurikulum 2013 tersebut itu menetukan agar ekstrakurikuler pramuka wajib dimasukan karena disitu ada nilai penanaman karakter, nilai penanaman sosial, dan nilai kepemimpinan terutama yang mendukung kegiatan pembelajaran dan positif." (Wawancara pada tanggal 7 April 2018 pukul 12.30 WIB). Pernyataan Bapak Ahmad Furqon didukung oleh Kepala SMP Negeri 1 Cipari R. Sri Pramana Budiarsa yang menyatakan bahwa "Karena memang ini program wajib dari pemerintah, dan sudah jelas membentuk karakter siswa dan tidak terkotak-kotak pramuka malah menyatukan. Hanya saja pramuka harus mengikuti perkembangan jaman, karena jika tidak kata wajib akan ditinggalkan, sebenarnya tidak perlu diwajibkan jika mengikuti perkembangan jaman." (Wawancara pada tanggal 18 April 2018 pukul 10.00). Berdasarkan hasil wawancara yang diperoleh dari informan utama dan pendukung yang telah ditetapkan oleh peneliti, diketahui dan didapatkan hasil terkait keadaan kegiatan kepramukaan di SMP Negeri 1 Cipari berjalan dengan baik dan sesuai dengan ketentuan yang sudah ditetapkan oleh pemerintah. Pembina pramuka menjalankan tugas dan kewajibannya untuk mengelola kegiatan kepramukaan di SMP Negeri 1 Cipari. Begitu juga dengan kepala SMP Negeri 1 Cipari yang telah melaksanakan kegiatan ekstrakurikuler pramuka dengan baik di SMP Negeri 1 Cipari. Berdasarkan pengamatan yang dilakukan, peneliti menemukan adanya fungsi yang berjalan saat kegiatan ekstrakurikuler pramuka dilaksanakan. Pembina pramuka sebagai pengarah kegiatan apa saja yang harus dilakukan pada latihan pramuka di minggu tersebut. Dewan penggalang melaksanakan tugasnya untuk mengarahkan anggota pramuka secara langsung dilapangan pada saat kegiatan kepramukaan berlangsung. Pembina pramuka memberikan nasihat kepada seluruh anggota pramuka tentang hal-hal yang berkaitan dengan kepramukaan.

$$
\text { Berdasarkan wawancara yang }
$$
dilakukan terhadap informan utama dan pendukung, peneliti menperoleh hasil bahwa strategi yang dilakukan oleh pembina pramuka dalam pembentukan karakter peduli sosial dilaksanakan dengan menanamkan secara langsung melalui nasihat-nasihat dan materi yang diperoleh dalam pendidikan kepramukaan. Selain itu kegiatan yang berkaitan langsung dengan nilai karakter pedulu sosial. Melalui pembina pramuka, dewan penggalang mendalami materi untuk disampaikan kepada adik-adik atau anggota pramuka yang dilatihnya. Sebagai contoh berdasarkan hasil observasi yang dilakukan oleh peneliti, dewan penggalang mahir memberikan materi saat kegiatan ekstra. Berdasarkan hasil wawancara yang dilakukan di SMP Negeri 1 Cipari didapatkan hasil bahwa pembentukan nilai karakter peduli sosial melalui pendidikan kepramukaan berpengaruh terhadap pembelajaran IPS, dengan kepercayaan diri yang dimiliki siswa, siswa menjadi lebih aktif di kelas. 
Terlebih lagi untuk saat ini yaitu dengan diterapkannya kurikulum 2013 yang menuntut siswa untuk lebih aktif di kelas. Berdasarkan hasil wawancara dan pengamatan yang dilakukan oleh peneliti terkait tentang kegiatan ekstrakurikuler pramuka dapat disimpulkan bahwa kegiatan ekstrakurikuler pramuka berjalan dengan sebagaimana mestinya di SMP Negeri 1 Cipari. Ada fungsi dan tujuan yang menjadikan kegiatan pramuka di SMP Negeri 1 Cipari dapat berjalan dengan baik dan sesuai dengan yang diharapkan. Pembentukan nilai karakter peduli lingkungan melalui pendidikan kepramukaan tidak bisa terlepas dari strategi yang digunakan oleh pembina pramuka. Strategi ini digunakan untuk memudahkan pembentukan karakter siswa yang memiliki nilai karakter peduli sosial. Bapak Ahmad Furqon, selaku pembina pramuka SMP Negeri 1 Cipari menyatakan bahwa "Strategi pembina pramuka yaitu dengan menerapkan nilai karakter peduli sosial dan peduli lingkungan disetiap kegiatan pramuka dengan kegiatan-kegiatan yang nyata dan dapat dirasakan siswa secara langsung." (Wawancara pada tanggal 7 April 2018 pukul 12.30 WIB). Berdasarkan wawancara yang dilakukan terhadap Informan utama dan pendukung, peneliti menperoleh hasil bahwa strategi yang dilakukan oleh pembina pramuka dalam pembentukan karakter peduli lingkungan dilaksanakan dengan menanamkan secara langsung melalui nasihat-nasihat dan materi yang diperloeh dalam pendidikan kepramukaan. Selain itu kegiatan yang berkaitan langsung dengan nilai karakter pedulu sosial. Melalui pembina pramuka, dewan penggalan mendalami materi untuk disampaikan kepada adik-adik atau anggota pramuka yang dilatihnya. Sebagai contoh berdasarkan hasil observasi yang dilakukan oleh peneliti, dewan galang mahir memberikan materi saat kegiatan ekstrakurikuler pramuka berlangsung. Berdasarkan wawancara yang dilakukan peneliti terhadap Informan utama dan pendukung dapat diketahui bahwa kegiatan yang mengandung nilai peduli lingkungan sudah dilakukan secara langsung, tidak hanya warga sekolah saja, namun masyarakat juga ikut merasakannya. Kegiatan kepramukaan dilakukan dengan cara yang baik. Pembina pramuka membawa anggota pramuka untuk melaksanakan kegiatan kerja bakti dan bersih lingkungan. Sehingga dari sana muncul sifat peduli terhadap lingkungan dan tanggung jawab terhadap lingkungannya. Dari hasil wawancara peneliti dengan kepala SMP Negeri 1 Cipari dapat diartikan bahwa profesionalisme seorang pembina pramuka itu penting dalam pelaksanaan pembentukan karakter peduli sosial siswa melalui pendidikan kepramukaan. Karena apabila pembina memiliki profesionalitas, makan akan membuat anggota pramuka menjadi teratur. Berdasarkan hasil wawancara yang dilakukan oleh peneliti dengan memperoleh data dari Informan utama dan Informan pendukung dapat disimpulkan bahwa walaupun kekurangan dan kendala itu selalu ada. Tetapi bagaimana cara untuk mengatasi kendala tersebut dan menjadikannya sebagai pendorong untuk meingkatkan prestasi dan menanamkan nilai karakter pada umumnya dan nilai karakter peduli sosial pada khususnya.

Dari hasil wawancara peneliti dengan kepala SMP Negeri 1 Cipari dapat diartikan bahwa profesionalisme seorang pembina pramuka itu penting dalam pelaksanaan pembentukan karakter peduli sosial siswa melalui pendidikan kepramukaan. Karena apabila pembina memiliki profesionalitas, makan akan membuat anggota pramuka menjadi teratur.

Berdasarkan hasil wawancara yang dilakukan oleh peneliti dengan memperoleh data dari informan utama dan informan pendukung dapat disimpulkan bahwa kendala terjadi karena adanya kekurangan dari individunya, baik dari anggota pramuka maupun dari seorang pembina pramuka. Namun disisi lain, sarana dan prasarana juga menjadi bagian sumbangsih dari kendala yang dialami.

\section{SIMPULAN}

Berdasarkan hasil penelitian dan pembahasan yang telah dipaparkan pada bab sebelumnya, maka peneliti dapat menarik kesimpulan beberapa kesimpulan sebagai 
berikut: nilai karakter peduli sosial diterapkan melalui pendidikan kepramukaan di SMP Negeri 1 Cipari. Materi pada kegiatan kepramukaan berkaitan erat dengan penerapan nilai karakter peduli sosial. Pramuka sebagai fasilitas untuk menanamkan karakter peduli sosial. Pembina memberi nasihat dan arahan kepada dewan penggalang yang selanjutnya dewan penggalang tersebut memberikan materi kepada anggota pramuka kelas VII. Selain itu pembina pramuka memiliki strategi tersendiri untuk membentuk karakter siswa yang memiliki nilai peduli sosial, yaitu dengan cara menggunakan metode-metode yang menarik, atraktif dan sesuai dengan siswa. Penerapan karakter peduli sosial dibuktikan secara nyata dengan adanya kegiatan bakti sosial kepada korban bencana alam.

Nilai karakter peduli lingkungan diterapkan melalui pendidikan kepramukaan di SMP Negeri 1 Cipari. Materi pada kegiatan kepramukaan berkaitan erat dengan penerapan nilai karakter peduli lingkungan, salah satunya adalah pemberian materi toga. Pramuka sebagai fasilitas untuk menamkan karakter peduli lingkungan. Pembina memberi nasihat dan arahan kepada dewan penggalang yang selanjutnya dewan penggalang tersebut memberikan materi kepada anggota pramuka kelas VII. Selain itu, pembina pramuka memiliki strategi tersendiri untuk membentuk karakter siswa yang memiliki nilai peduli lingkungan, yaitu dengan cara menggunakan metode-metode yang menarik, atraktif dan sesuai dengan siswa. Penerapan karakter peduli sosial dibuktikan secara nyata dengan adanya kegiatan kerja bakti yang dilakukan setelah kegiatan perkemahan dan setiap sebelum melaksanakan kegiatan ekstrakurikuler pramuka.

Faktor pendorong dan penghambat dalam menerapkan karakter peduli sosial dan peduli lingkungan di SMP Negeri 1 Cipari yaitu adanya pengetahuan, keterampilan dan profesionalisme yang dimiliki oleh pembina pramuka. Pembina pramuka dapat mengorganisasikan kegiatan pramuka dengan baik sehingga sesuai dengan tujuan dari pendidikan kepramukaan. Motivasi siswa yang ada menjadi pendorong semangat siswa megikuti kegiatan pramuka. Sehingga proses penerapan nilai karakter peduli sosial dapat dijalankan. Sarana dan prasarana pramuka di SMP Negeri 1 Cipari cukup memadai. Namun, kurangnya minat siswa menjadi kendala tersendiri yang menghambat proses penerapan nilai karakter peduli sosial dan peduli lingkungan. Kehadiran siswa pada kegiatan pramuka merupakan hal yang penting. Saran yang diberikan yaitu: pembina hendaknya melakukan kontrol dan pendekatan kepada siswa atau anggota pramuka yang kurang disiplin dan bertanggungjawab sehingga dapat mengarahkan siswa untuk aktif berpartisipasi dalam kegiatan kepramukaan. Siswa diharapkan dapat menjalankan segala kegiatan yang ada dalam ekstrakurikuler pramuka dengan penuh kesadaran dan kemauan dari diri sendiri, sehingga dapat menjalankan kegiatan dengan baik dengan penuh keikhlasan.

\section{DAFTAR PUSTAKA}

Gunawan, Heri. 2012. Pendidikan Karakter Konsep dan Implementasi. Bandung: Alfabeta.

http://www.tribunnews.com/regional/2018/02/04/ aniaya-guru-budi-hingga-meninggal-lamahukuman-siswa-yang-jadi-tersangka-buatnetizen-geram (Diakses pada hari Senin, 12 Februari 2018 pukul 19.15 WIB)

Kemendiknas. 2011. Panduan Pendidikan karakter di sekolah menengah pertama. Jakarta: Kementerian Pendidikan Nasional Direktorat jenderal pendidikan dasar direktorat pembinaan sekolah menengah pertama.

Keputusan Kwartir Nasional Gerakan Pramuka Nomor: 200 Tahun 2011 Tentang Panduan Teknis Kursus Pembina Pramuka Mahir.

Moleong, Lexy. 2010. Metode Penelitian Kualitatif. Jakarta: UI Press. 